\title{
Effects of Static Magnetic Field and Pulsed Electromagnetic Field on Viability of Human Chondrocytes in vitro
}

\author{
Š. ŠTOLFA ${ }^{1}$, M. ŠKORVÁNEK ${ }^{2}$, P. ŠTOLFA ${ }^{2}$, J. ROSOCHA ${ }^{3}$, G. VAŠKO ${ }^{1}$, \\ J. $\mathrm{SABO}^{2}$ \\ ${ }^{1}$ Department of Orthopedics and Traumatology of Locomotory Apparatus, Faculty of Medicine, \\ P.J. Šafárik University, Košice, ${ }^{2}$ Department of Medical Biophysics, Faculty of Medicine, \\ P.J. Šafárik University, Košice, ${ }^{3}$ Associated Tissue Bank, Faculty of Medicine of P.J. Šafárik \\ University and L. Pasteur Faculty Hospital, Košice, Slovakia
}

Received May 23, 2007

Accepted May 29, 2007

On-line available May 31, 2007

\begin{abstract}
Summary
Effects of electromagnetic fields (EMFs) on human cell lines were described in numerous studies, but still many questions remain unanswered. Our experiment was designed with the aim of studying the effects of EMFs on the metabolic activity of chondrocytes in vitro. Human chondrocyte in vitro cultures, cultured in medium supplemented with $20 \%$ fetal calf serum, were exposed to static magnetic field (SMF) (intensity of $0.6 \mathrm{~T}$ ) and pulsed electromagnetic fields (PEMF) (21.2 MHz period of $15 \mathrm{~ms}$, burst duration of $2 \mathrm{~ms}$, amplification $3 \mathrm{dBm}(0.1 \mathrm{~V})$ and maximum output of $250 \mathrm{~W}$ ) continually for $72 \mathrm{~h}$. After the exposure, viability was determined using the MTT test and compared with a nonexposed control culture. As compared to the control sample the exposure to SMF resulted in a statistically significant increase $(p<0.001)$ in viability. However, the increase of viability after PEMF exposure was not significant. This could be due to the frequency dependent effect on human cells. The experiments demonstrated that magnetic fields, using the above parameters, have a positive effect on the viability of human chondrocytes cultured in vitro.
\end{abstract}

Key words

Chondrocytes $\bullet$ Magnetic field $\bullet$ Osteoarthritis

\section{Introduction}

Osteoarthritis (OA) is the most common articulation disorder of the hyaline cartilage and subchondral bone and is often seen in knee joints by the age of 70. Pathological changes of the weight-bearing joints are common at the age of 40 . The disease is responsible for substantial direct and indirect socioeconomic cost. The treatment options are unsatisfactory. Treatment of OA is difficult and only few methods are available. Surgical treatment has limited indications and is not sufficient, nonsurgical treatment involves mostly medication with NSA (non-steroid antiphlogistics) or/and SYSDOA (symptomatic slow acting drugs in osteoarthritis) and adjuvant therapy with different electromagnetic fields. So autologous chondrocyte transplantation is used in its treatment of joint lesions to avoid a secondary OA. The European League Against Rheumatology has now rated pulsed electromagnetic field treatment for $\mathrm{OA}$ as $1 \mathrm{~B}$ evidence 
and it received a B rating for strength of recommendation. The decision was made since no effects were calculable from previous data, poor practicality of delivery to the patient population in most cases and due to economic considerations.

The effects of EMFs on human cells were described in numerous in vitro and in vivo studies (Ciombor et al. 2002, Wilmot et al. 1993, Dini and Abbro 2005, Yoshizawa et al. 2002, Gál et al. 2005). The extracellular matrix of the hyaline cartilage is piezoelectric, so that it is capable of converting electromagnetic oscillations to mechanical vibrations and vice versa (Jacobson et al. 2001). Certain authors have described positive effects on growth and on the production of extracellular matrix in an endochondral ossification model (Ciombor et al. 2002; Indouraine et al. 2001). On the other hand also negative effects on the chondrogenic layer of the articular zone after exposure to PEMF at a the frequency of $75 \mathrm{~Hz}$ in rats were described (Wilmot et al. 1993). In contrast to those results SMFat an intensity of $6 \mathrm{mT}$ has a negative effect on cell shape in some human cells (Dini and Abbro 2005).

EMFs have positive effects on the metabolism of tissues through of hyperemization. The aim of our study was to analyze the effects of EMFs on human chondrocytes in vitro with the exclusion of that effect. Our choice was based on different studies of EMF effects describing mostly effects of pulsed electromagnetic fields (PEMFs). The selection of chondrocytes, as the cellular object of our study, has also been based on studies reporting about autologous transplantation of in vitro cultivated chondrocytes used in treatment of articular lesions (Bačenková et al. 2001, Rosocha et al. 2002). We preferred static magnetic field (SMF) and pulsed EMFs (PEMFs), because many instruments use this kind of EMFs in clinical practice with positive effects after application in therapy of degenerative arthrosis (Hinman et al. 2002).

\section{Methods}

\section{Isolation and cultivation of chondrocytes}

Human adult articular cartilage was obtained from human tissue donors respecting all ethical rules of Slovak law regulations. Cartilage from the lateral region of the lateral femur condyle in an amount of 3-4 $\mathrm{mm}^{3}$ was procured. The cartilage from donors not later than 12 $\mathrm{h}$ after death (4 males, age 25-50 years) was used. Donors had no autoimmune, or metabolic disease, or malignancy in their history. Cartilage after the procurement was transported in a medium composed of phosphate buffered saline (PBS) with antibiotics (100 $\mathrm{U} / \mathrm{ml}$ penicillin, $100 \mu \mathrm{g} / \mathrm{ml}$ streptomycin and $0.25 \mu \mathrm{g} / \mathrm{ml}$ amphotericin B) (Gibco BRL). The separation of chondrocytes started not later than 6 hours after the procurement, cartilage specimen was cut into small pieces and digested with type II collagenase $(1 \mathrm{mg} / \mathrm{ml})$ (Gibco BRL) in a Nutrient mix F 12 (NUTmix) medium (Gibco BRL) by incubation for $16-18 \mathrm{~h}$ at $37^{\circ} \mathrm{C}$. The cell suspension was cleared on a cell sieve (pore diameter 40 $\mu \mathrm{m})$ (Falcon). Chondrocytes after digestion were rinsed in the medium and centrifuged at $100 \mathrm{~g}$ for $15 \mathrm{~min}$. Viability and number of isolated cells were estimated by vital staining using trypan blue. Cells were plated in complete medium on cell culture flasks (Falcon) for adherent cell lines. Chondrocytes were grown in NUTmix supplemented with $20 \%$ fetal calf serum (FCS) (Gibco BRL), insulin-transferrin-selenium A $(10 \mu \mathrm{l} / \mathrm{ml})$ and antibiotics (100 U/ml penicillin, $100 \mu \mathrm{g} / \mathrm{ml}$ streptomycin and $0.25 \mu \mathrm{g} / \mathrm{ml}$ amphotericin B) (Gibco BRL) and incubated at $37{ }^{\circ} \mathrm{C}$ in $5 \% \mathrm{CO}_{2}$ atmosphere. Cells normally reached confluence after 14-21 days. Cells were consequently isolated from the cell culture flasks by trypsinization $-0.1 \%$ trypsin/EDTA (Gibco). The cell suspension was then rinsed three times in medium and thereafter resuspended in complete cultivation medium and plated into $75 \mathrm{~cm}^{2}$ cell culture flasks or used in experiment in 96-well tissue culture plates for adherent cell lines (Sarstedt).

\section{Generators of EMF}

Static magnetic field (SMF) with an intensity of 0.6 T (Sabo et al. 2002) and high-frequency pulsed EMF (PEMF) with a frequency of 21.2 MHz, period of $15 \mathrm{~ms}$, burst duration $2 \mathrm{~ms}$, amplification $3 \mathrm{dBm}(0.1 \mathrm{~V})$ and maximum output of $250 \mathrm{~W}$ were used for exposure of chondrocytes in the experiments.

\section{Experiment and data evaluation}

Microplate with 32 filled wells with 7000 cells per well and 16 blank wells was inserted into EMF at 37 ${ }^{\circ} \mathrm{C}$ in $5 \% \mathrm{CO}_{2}$ atmosphere. After $72 \mathrm{~h}$ of exposure to EMF we added to every well $10 \mu \mathrm{l}$ of 3-(4,5-dimethyl-2thiazolyl)-2,5-diphenyl-2H-tetrazolium bromide (MTT) at a concentration of $5 \mathrm{mg} / \mathrm{ml}$ and incubated for 4-5 h; thereafter we added to each well $100 \mu \mathrm{l}$ SDS and incubated for subsequent $12 \mathrm{~h}$. The absorbance of the reduced MTT was determined spectrophotometricaly 
$(540 \mathrm{~nm})$ in an ELISA reading device MRX Dynatech (Great Britain).

\section{Statistical analysis}

The results were evaluated using STATSDIRECT software ver. 2.5.2 by the Student unpaired t-test and the Mann-Whitney U-test.

\section{Results and Discussion}

Three experiments with different starting concentrations of chondrocytes without application of EMFs were performed. The starting concentrations of 14 $\times 10^{3}, 7 \times 10^{3}, 3.5 \times 10^{3}$ and $1.75 \times 10^{3}$ cells per well were used. In those experiments, the highest metabolic activity after $72 \mathrm{~h}$ of cultivation was observed in the cultures with the starting concentration of $7 \times 10^{3}$ cells per well, because chondrocytes did not form yet a compact monolayer and therefore were not affected by cell-cell contact inhibition. Low energy PEMFs affect growth of human chondrocytes in vitro (Fiovanti et al. 2002), regardless of age and sex of donor (Indouraine et al. 2001). Stimulation effects are also dependent on the presence of growth factors (Pezzetti et al. 1999) and density of chondrocytes in cell culture (De Mattei et al. 2001), which might be due to cell-cell contact inhibition of adherent cell lines. The above data correspond to our experiments with different starting cell numbers per well. The most significant stimulation of chondrocyte growth was observed after $72 \mathrm{~h}$ of cultivation when $7 \times 10^{3}$ chondrocytes per well were applied. Using higher concentrations of chondrocytes per well would cause formation of a compact monolayer earlier than in $72 \mathrm{~h}$. Therefore, we could not observe significant changes of chondrocyte growth because of cell-cell contact inhibition at the higher starting concentration of $14 \times 10^{3}$ cells per well.

On the basis of those experiments the starting concentration of $7 \times 10^{3}$ cells per well was estimated as suitable to carry out the following experiments. Subsequently a series of five experiments with a starting concentration of 7000 cells per well in static and pulsed EMFs were performed. Results of the MTT test are shown in Fig. 1 and 2 and in Tables 1 and 2. All experiments with SMF resulted in a highly significant statistical difference $(p<0.001)$ between the control and the exposed samples of chondrocytes. Those data indicate that SMFs induce a significant increase in metabolic activity in all the experiments after 72-h application of

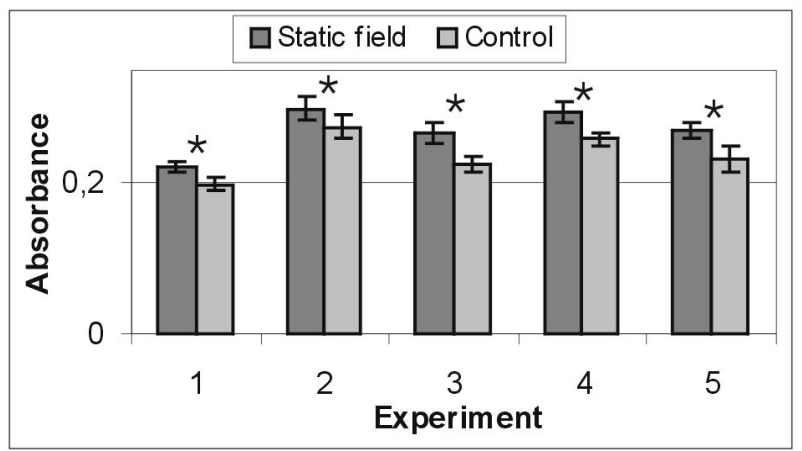

Fig. 1. Average absorbance values of MTT test of an experiment with static magnetic field compared with control group.

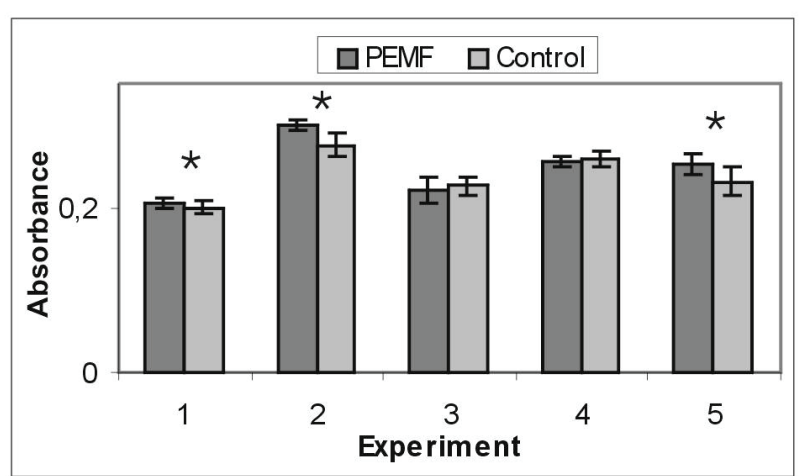

Fig. 2. Average absorbance values of experiments with pulsed magnetic field compared with control group.

SMF. The results correspond with positive effects of EMFs presented in clinical studies (Hinman et al. 2002, Trock et al. 1993). The data are in diagreement with the results of a similar study performed on leukemic cells HL-60 (Sabo et al. 2002), which suggests differences in the influence of EMFs on different cell types.

Experiments with high-frequency PEMFs show positive effects on chondrocyte metabolism, but these results were not achieved in all experiments which differ from earlier published studies in this field (Ciombor et al. 2002, Fiovanti et al. 2002, Indouraine et al. 2001), where significant effects on proliferation, metabolism, maturation and matrix proliferation of chondrocytes were observed. Statistic analysis demonstrated a highly significant difference in the first, second and fifth experiment $(p<0.001)$. In the third and fourth experiment there was no significant difference found $(p>$ 0.05 ). This phenomenon may be due to the parameters of PEMFs that differed from the above papers on the variability of the response of chondrocytes, depending on the age of the tissue donor. Positive effects on matrix proliferation were present also after stimulation of 
Table 1. Results of experiments with static magnetic field compared with control group.

\begin{tabular}{llllll}
\hline & 1st experiment & 2nd experiment & 3rd experiment & 4th experiment & 5th experiment \\
\hline $\begin{array}{l}\text { Difference } \\
\text { static field/control }\end{array}$ & $12,40 \%$ & $8,91 \%$ & $17,99 \%$ & $13,76 \%$ & $16,34 \%$ \\
SD & $3,01 \%$ & $5,27 \%$ & $4,87 \%$ & $4,48 \%$ & $3,86 \%$ \\
\hline
\end{tabular}

Table 2. Results of experiments with pulsed magnetic field compared with control group.

\begin{tabular}{llllll}
\hline & 1st experiment & 2nd experiment & 3rd experiment & 4th experiment & 5th experiment \\
\hline $\begin{array}{l}\text { Difference } \\
\text { PEMF/control }\end{array}$ & $3,27 \%$ & $8,75 \%$ & $2,30 \%$ & $1,78 \%$ & $9,23 \%$ \\
$S D$ & $2,69 \%$ & $2,35 \%$ & $7,17 \%$ & $2,72 \%$ & $4,93 \%$ \\
\hline
\end{tabular}

chondrocytes with high-frequency PEMFs in other laboratories (Mohamed-Ali et al. 1995).

In conclusion, we have demonstrated that static magnetic field and pulsed electromagnetic fields stimulate metabolic activity of chondrocytes in vitro. The results presented here suggest that a static magnetic field is more appropriate for stimulation of metabolic activity of chondrocytes than pulsed electromagnetic fields of megahertz frequencies. This fact can be utilized for clinical application of static magnetic field during in vitro cultivation of chondrocytes for autologous transplantation in the treatment of articular lesions in the line of evidence based medicine.

\section{Acknowledgements}

This study was supported by Scientific Grant Agency of the Slovak Ministry of Education and the Slovak Academy of Sciences (VEGA 1/2269/05).

\section{References}

BAČENKOVÁ D, ROSOCHA J, ŠVIHLA R, VAŠKO G, BODNÁR J: Repair of knee chondral defectu by a comination of autologous chondrocytes and osteochondral allografts - an animal model (in Slovak). Acta Chir Orthop Traum Cechoslov 68: 363-368, 2001.

CIOMBOR DM, LESTER G, AARON RK, NEAME P, CATERSON B: Low frequency EMF regulates chondrocyte differentiation and expression of matrix proteins. J Orthop Res 20: 40-50, 2002.

De MATTEI M, CARUSO A, PEZZETTI F, PELLATI A, STABELLINI G, SOLLAZZO V, TRANIA GC: Effects of pulsed electromagnetic fields on human articular chondrocyte proliferation. Connect Tissue Res 42: 269-279, 2001.

DINI L, ABBRO L: Bioeffects of moderate-intensity static magnetic fields on cell cultures. Micron 36: 195-217, 2005.

FIOVANTI A, NERUCCI F, COLLODEL G, MARKOLL R, MMARCOLONGO R: Biochemical and morphological study of human articular chondrocytes cultivated in the presence of pulsed signal therapy. Ann Rheum Dis 61: 1032-1038, 2002.

FITSZIMMONS RJ, RAYBAY JT, MAGEE FP, BAYLINK DJ: Combined magnetic-fields increased net calcium flux in bone-cells. Calcif Tissue Int 55: 376-380, 1994.

GÁL P, KILÍK R, ŠPAKOVÁ T, PATAKY S̆, SABO J, POMFY M, LONGAUER F, HUDÁK R: He-Ne laser irradiation accelerates inflammatory phase and epithelization of skin wound healing in rats. Biologia 60: 691696, 2005.

HINMANN MR, FORD J, HEYL H: Effects of static magnets on chronic knee pain and physical function: A doubleblind study. Altern Ther Health Med 8: 50-55, 2002. 
INDOURAINE A, PETERSEN JP, PFÖRINGER W: Auswirkungen NF-gepluster elektromagnetischer Felder auf die Proliferation von Chondrozyten. Sportverletz Sportchaden 15: 22-27, 2001.

JACOBS JI, GORMAN R, YAMANASHI WS, SAXENA BJ, CLAYTON L: Low-amplitude extremely low frequency magnetic fields for the treatment of osteoarthritic knees: a double-blind clinical study. Altern Ther Health Med 7: 54-67, 2001.

MENDEZ RG: Three molecular mechanisms to explain some biological effects of electromagnetic fields and hypogravity. Med Hypotheses 52: 239-245, 1999.

MOHAMED-ALI H, SCHELLER M, HETSCHER M, KOHLSMANN S, KRAMER KD: Action of a high-frequency magnetic field on the cartilage matrix in vitro. BioelectrochemBioenerget 37: 25-29, 1995.

PESSINA GP, ALDINUCCI C: Short cycles of both static and pulsed electromagnetic fields have no effect on the induction of cytokines by peripheral blood mononuclear cells. Bioelectromagnetics 18: 548-554, 1997.

PEZETTI F, DE MATTEI M, CARUSO A, CADOSSI R, ZUCHINI P, CARINCI F, TRIANA GC, SOLLAZZO V: Effects of pulsed electromagnetic fields on human chondrocytes: An in vitro study. Calcif Tissue Int 65: 396401, 1999.

ROSOCHA J, VAŠKO G, BAČENKOVÁ D, HRBKOVÁ H, ŠVIHLA R, VARGA G, JENČA A, ČELLÁR R, BOBÁK L, KLADEKOVÁ Z, BIELEK J, ŠČERBÁKOVÁ A, NEMEC P: Preliminary clinical experience with the preparation and therapeutic use of autologous osteoblasts and chondrocytes. Cell Tissue Banking 3: $127-132,2002$.

SABO J, MIROSSAY L, HOROVČÁK L, ŠARIŠSKÝ M, MIROSSAY A, MOJZIŠ J: Effects of static magnetic field on human leukemic cell line HL-60. Bioelectrochemistry 56: 227-231, 2002.

TROCK DH, BOLLET AJ, DYER RH, FIELDING LP, MINKER WK, MARKOLL R: A double-blind trial of the clinical effects of pulsed electromagnetic-fields in osteoarthritis. $J$ Rheumatol 20: 456-460, 1993.

VAUGHAN TE, WEAVER JC: Molecular change due to biomagnetic stimulation and transient magnetic fields: mechanical interference constraints on possible effects by cell membrane pore creation via magnetic particles. BioelectrochemBioenerget 46: 121-128, 1998.

WILMOT JJ, CHIEGO JR DJ, CARLSON DS, HANKS CT, MOSKWA JJ: Autoradiographic study of the effects of pulsed electromagnetic fields on bone and cartilage growth in juvenile rats. Arch Oral Biol 38, 67-74, 1993.

YOSHIZAWA H, TSUCHIYA T, MIZOE H, OZEKI H, KANAO S, YOMORI H, SAKNE C, HASEBE S, MOTOMURA T, YAMAKAWA T, MIZUNO F, HIROSE H, OTAKA Y: No effect of extremely lowfrequency magnetic field observed on cell growth or initial response of cell proliferation in human cancer cell lines. Bioelectromagnetics 23: 355-368, 2002.

\section{Corresponding author}

J. Sabo, Department of Medical Biophysics, Faculty of Medicine, P.J. Šafárik University, Tr. SNP 1, 04011 Košice, Slovakia. E-mail: jan.sabo@upjs.sk 